University of Nebraska - Lincoln

DigitalCommons@University of Nebraska - Lincoln

Faculty Publications from the Harold W. Manter Laboratory of Parasitology

1975

\title{
Rabies in Experimentally Infected Bears, Ursus spp., with Epizootiologic Notes
}

Robert L. Rausch

Arctic Health Research Center, rausch@u.washington.edu

Follow this and additional works at: https://digitalcommons.unl.edu/parasitologyfacpubs

Part of the Parasitology Commons

Rausch, Robert L., "Rabies in Experimentally Infected Bears, Ursus spp., with Epizootiologic Notes" (1975). Faculty Publications from the Harold W. Manter Laboratory of Parasitology. 546.

https://digitalcommons.unl.edu/parasitologyfacpubs/546

This Article is brought to you for free and open access by the Parasitology, Harold W. Manter Laboratory of at DigitalCommons@University of Nebraska - Lincoln. It has been accepted for inclusion in Faculty Publications from the Harold W. Manter Laboratory of Parasitology by an authorized administrator of DigitalCommons@University of Nebraska - Lincoln. 
Rausch in Zentralblatt für Veterinarmedizin Reihe B--Journal of Veterinary Medicine, Series B: Infectious Diseases, Immunology, Food, Hygiene and Veterinary Public Health (1975) 22.

This article is a U.S. government work, and is not subject to copyright in the United States.

Zbl. Vet. Med. B, 22 420-437 (1975)

(C) 1975 Verlag Paul Parey, Berlin und Hamburg

ISSN 0044-4294/ASTM-Coden: ZVRBA2

From the Arctic Health Research Center, Center for Disease Control, U. S. Public Health Service, Fairbanks, Alaska

\section{Rabies in Experimentally Infected Bears, Ursus spp., with Epizootiologic Notes}

By

R. L. RAUSCH

With 7 figures and 2 tables

(Received for publication October 11, 1974)

In Alaska, where bears are relatively numerous, ostensibly unprovoked attacks by bears on man have been reported almost every year. Survivors of ten have been severely injured, with multiple, deeply penetrating wounds, typically lacerations about the head, caused by the teeth of the animals. When brown (grizzly) bears, Ursus arctos Linnaeus, are involved, injuries to the head have often been fatal. Less severe injuries have usually been attributable to black bears, $U$. americanus Pallas. The possibility that such attacks might have been made by rabid animals is an important consideration in the treatment of injured patients. Since rabies is not enzootic in the interior of Alaska (RAUSCH, 1972), where most of the more recent attacks have occurred, and since the virus has not been recorded from wild bears in Alaska, physicians have been reluctant to superimpose preventive measures against this disease. Whether bears might have any role in the natural cycle of rabies in this northern region is an unresolved question.

In order to determine their relative susceptibility to infection and their potential capacity for transmitting the virus of rabies, several bears obtained during the period $1963-73$ were inoculated with the virus experimentally. The present paper reports the results of this study and discusses the epizootiology of rabies in a region where bears are abundant.

\section{Material and Methods \\ Experimental Animals}

Ten black bears were selected from animals made available by the Alaska Department of Fish and Game. All were received in spring and early summer as unweaned young, most of which had lost their mothers; all were captured in central or south-central Alaska, where rabies is not enzootic. The 3 brown bears, an orphaned litter captured in east-central Alaska, had been subjects in another investigation, with the Alaska Department of Fish and Game, the 
Rausch in Zentralblatt für Veterinarmedizin Reihe B--Journal of Veterinary Medicine, Series B: Infectious Diseases, Immunology, Food, Hygiene and Veterinary Public Health (1975) 22.

nature of which precluded their later release. The use of brown bears as experimental animals hitherto has been avoided, because of their decreasing numbers.

After weaning, the bears were caged separately and fed specially prepared or commercial diets. None was inoculated with the virus before October of the first year of life, when about 8 months old (assuming a birth-date of 1 February). Since the bears were maintained in an active state throughout the year, they grew continuously and after the first summer of life were more advanced in physical development than wild bears of the same chronological age (cf. RAuSCH, 1967). Laboratory-reared carnivores of other species served as inoculated controls: dogs (beagles and dingoes); arctic foxes, Alopex lagopus (Linnaeus); and coyotes, Canis latrans Say. The arctic foxes had been raised at the Alaska Experimental Fur Farm, Petersburg. Albino mice of the HA/ICR strain were used in titrating the virus.

\section{Source and Storage of Virus}

Three viral isolates from naturally infected foxes were used: 1 . from a naturally exposed arctic fox that was captured at Point Barrow in November 1961, and which became rabid in captivity, one passage was made to a red fox, Vulpes vulpes (Linnaeus), from which the inoculum was obtained; the isolate was passed from the red fox to an arctic fox, and then to a dog, which was a source of virus used; 2 . from a red fox killed at Ugashik (upper Alaska Peninsula) in October 1970; and 3. from a red fox killed at Nome (Seward Peninsula) in August 1972. Suspensions of brain, 20\% in phosphate-buffered saline ( $\mathrm{pH} 7.6-7.7)$, prepared in a blender, were divided into $5 \mathrm{ml}$. aliquots and stored at -65 to $-70^{\circ} \mathrm{C}$.

\section{Titration of Virus}

Three- to 4-week-old mice were inoculated intracerebrally with $0.03 \mathrm{ml}$. of brain-suspension diluted serially to $10^{-6}$ with phosphate-buffered saline. Six mice were inoculated with each dilution. Brain-suspensions that had been stored for several months were retitrated before use. Salivary glands from carnivores were similarly prepared and titrated in mice. Mice were held for 21 days, after which survivors were destroyed. Titres were calculated by the method of REED and MUENCH (1938).

\section{Inoculation of Experimental Animals}

Carnivores were inoculated unilaterally in the dorsolateral muscles of the neck, just posterior to the atlas. Procedures involving bears were carried out after the animals had been immobilized by phencyclidine hydrochloride, injected intramuscularly by means of a gas-propelled dart. Since naturally occurring rabies is almost exclusively a disease of foxes in arctic and subarctic regions, the amount of virus given to the bears was near or somewhat greater than the maximum amount that might be excreted by rabid foxes in $0.03 \mathrm{ml}$. of saliva (Sikes, 1962).

In most cases the bears were observed for at least 6 months following inoculation, after which survivors were killed. Eighty-four days preceding inoculation, two of the brown bears had been exposed per os to the indigenous northern serotype of Brucella suis (type 4), after which they developed agglutinating antibodies (L. G. Miller and K. A. Neiland, personal communication). Although there is evidence that animals infected by $B$. abortus may have increased resistance to viral infections (MUYEMBE et al., 1972), both brown bears became rabid. The third brown bear received only rabies virus. 


\section{Diagnostic Tests and Histological Examination}

The presence of rabies virus in the experimentally infected carnivores was confirmed at the Rabies Reference Diagnostic Laboratory, Center for Disease Control, Atlanta, by means of the fluorescent antibody test. The virus was also identified in electron micrographs of brain-tissue from 1 brown bear and from a mouse that had received the same inoculum. For light microscopy, brains of rabid animals were fixed in $10 \%$ formalin solution, after which selected tissues (cerebrum, cerebellum, hippocampus, pons, thalamus, cerebral peduncle, and medulla) were embedded by the paraffin method, cut at $0.005 \mathrm{~mm}$., and stained in hematoxylin-eosin, luxol fast blue, and Schleifstein's stain. Selected sections were stained also by other methods. For comparison, similar materials were prepared from a normal, laboratory-reared black bear. For electron microscopy, the tissue was cut into small fragments, fixed in $2 \%$ glutaraldehyde in sodium cacodylate buffer $(\mathrm{pH} 7.1)$, post-fixed in $1 \%$ osmium tetroxide, embedded in a mixture of Araldite and Epon (Mollenhauer, 1964), and cut on a Porter-Blum MT-2 ultramicrotome with a diamond knife. Sections were examined and photographed by means of a JEM 6-AS electron microscope.

\section{Results}

An indication that bears might be comparatively resistant to infection by rabies virus was obtained in 1963 , when a black bear inoculated with 1,000 $\mathrm{MLD}_{50}$ of the virus showed no signs of disease over a 5 -month period, while a $\mathrm{dog}$ and 3 arctic foxes that had received $100 \mathrm{MLD}_{50}$ of the same inoculum died of rabies in 67 to 106 days. Table 1.

Results obtained with bears in the present study are summarized in

\section{Clinical Characteristics of Rabies in Bears}

As in experimentally infected carnivores of other species, the clinical course of rabies in bears was somewhat varied, and the clinical manifestations

Table 1

Summary of results obtained in bears experimentally inoculated with rabies virus

\begin{tabular}{|c|c|c|c|c|c|c|}
\hline \multirow[b]{2}{*}{ Species } & \multirow[b]{2}{*}{$\begin{array}{l}\text { Inoculum } \\
\left(M L D_{50}\right)\end{array}$} & \multicolumn{3}{|c|}{ Post - inoculation } & \multirow[b]{2}{*}{$\begin{array}{l}\text { Approx, age } \\
\text { at death } \\
\text { (months) }\end{array}$} & \multirow[b]{2}{*}{$\begin{array}{c}\text { Titre } \\
\text { (Salivary gland) }\end{array}$} \\
\hline & & $\begin{array}{l}\text { Onset of } \\
\text { signs } \\
\text { (day) }\end{array}$ & $\begin{array}{l}\text { Death } \\
(\text { day })\end{array}$ & $\begin{array}{l}\text { Survivors } \\
\text { observed } \\
\text { (months) }\end{array}$ & & \\
\hline \multirow[t]{10}{*}{ U. americanus } & 500 & - & - & 10.5 & 19 & - \\
\hline & 1000 & - & - & 11,0 & 19 & - \\
\hline & 1000 & - & - & 5.0 & 17 & - \\
\hline & 1000 & 65 & 70 & - & 13 & $10^{-1.4}$ \\
\hline & 5000 & - & - & 6.5 & 15 & - \\
\hline & 5000 & - & - & 7.0 & 13 & - \\
\hline & 5000 & - & - & 8.0 & 17 & - \\
\hline & 5000 & 19 & 20 & - & 8 & Neg. \\
\hline & 10000 & - & 81 & - & 8 & Neg. \\
\hline & 20000 & 27 & 30 & - & 31 & $10^{-1.2}$ \\
\hline \multirow[t]{3}{*}{ U. arctos } & 5000 & 22 & 25 & - & 14 & Neg. \\
\hline & 10000 & 16 & 18 & - & 8 & Neg. \\
\hline & 10000 & 16 & 18 & - & 14 & Neg. \\
\hline
\end{tabular}

* Non-specific death. 
Rausch in Zentralblatt für Veterinarmedizin Reihe B--Journal of Veterinary Medicine, Series B: Infectious Diseases, Immunology, Food, Hygiene and Veterinary Public Health (1975) 22.

differed also with species of bear. Early signs of the disease were subtle, their detection requiring familiarity with the usual behavior of the individual animals. Two cases each in black bears and brown bears are briefly described. For the first animal, the source of the virus was the red fox from Ugashik, and for the others, the red fox from Nome.

1. A female black bear, approximately 10 months old, received 1,000 $M L D_{50}$ of virus on 30 November. Sixty-four days later, on the morning of 2 February, the animal was immobilized by an injection of phencyclidine hydrochloride for routine withdrawal of blood. The following morning the bear was slightly stuporous and appeared not to have recovered from the effect of the drug. While standing, it rested its head on a food-pan attached to the front of the cage. Objects inserted into the cage were ignored, but the animal would strike out with the fore-feet when touched. No attempt was made to bite. On the second day after onset of clinical signs, the condition of the animal remained unchanged, but it frequently scratched its neck with the rear feet and the genital area with the fore-feet. It consumed no food and drank little or no water. The animal's condition had deteriorated somewhat on the third day; it persisted in abrading the genital area, ignored objects inserted into the cage, and did not react to slightly painful stimuli (pinching of an ear by hand). On the fourth day, the animal was semicomatose, but by the following morning its condition had improved, and it was able to stand and readily drank water. By late afternoon, however, the bear was prostrate and had difficulty in rising to its feet; attempts to drink involved deep immersion of the muzzle, but whether any water was swallowed could not be confirmed. Increased salivation or an indication that the mandibular muscles were paralyzed was not observed. The animal's condition worsened thereafter, and death occurred in the early morning of the sixth day after clinical signs were first observed ( 8 February). Weight at death was $29 \mathrm{~kg}$.

2. An adult male black bear, age approximately 30 months, received $20,000 \mathrm{MLD}_{50}$ of virus on 10 October. On the 26th day following inoculation ( 5 November), the animal did not eat, and a definite change in behavior was evident by $7: 30 \mathrm{a}$. $\mathrm{m}$. of the next day; the bear seemed restless and no longer moved to the back of the cage when approached, and salivation had increased. The animal made no attempt to bite a wooden stick inserted into the cage and was not aggressive. By the morning of the second day after onset, the bear was salivating profusely, with the mouth held slightly open, and could neither eat nor drink, although the muzzle was frequently immersed in the water; when the water-pan was filled by means of a hose, the stream of water elicited no response. Occasional mild convulsions occurred later, and by late afternoon the animal's tongue protruded most of the time, and the lower lips were flaccid. The bear was restless, but moved slowly and the rear legs were spread in standing; movements of the head were rapid and erratic. Respirations were $56 / \mathrm{min}$. By the morning of the third day, the bear moved about with lowered head; the tongue protruded, and dripping of saliva was constant. There were frequent tremors of the muscles of the nose and muzzle, and the animal changed position constantly, whether standing or recumbent. The ears were held erect at all times, as when normally alert. When a stick was inserted into the cage, the animal struck it with the fore-feet, but attempts to bite were feeble, probably indicating some degree of paralysis of the mandibular musculature. By late morning, respirations had increased to $84 / \mathrm{min}$.; the animal was weak and had become unstable, occasionally falling. In the afternoon, the bear had greater difficulty in standing; convulsions resumed, with seizures attaining a frequency of $2-3 / \mathrm{min}$. by $3: 00$ p.m. By $4: 00$ p. m., it was unable to 
Rausch in Zentralblatt für Veterinarmedizin Reihe B--Journal of Veterinary Medicine, Series B: Infectious Diseases, Immunology, Food, Hygiene and Veterinary Public Health (1975) 22.

rise to its feet; convulsions were more frequent, with seizures lasting from 10 to 35 seconds. The animal became comatose within about an hour, and death occurred during the night. The bear weighed $100 \mathrm{~kg}$.

3. A male brown bear, age approximately 13 months, received 10,000 $\mathrm{MLD}_{50}$ of virus on 5 March. On the 14 th day following inoculation, the animal was unusually irritable, but definite signs of abnormality were not noted until the 16th day (21 March). At approximately $5: 00$ p. m., it was observed that the animal would not raise its head directly upward, but rotated it to the left or right, possibly because of pain at the site of inoculation. On the next day, its behavior was essentially normal, although no food was consumed and it had thrown the contents of the food-container onto the floor. On the afternoon of the third day following onset of clinical signs, at 2:30 p. m., when the water-pan was being filled, the bear became suddenly enraged, attacking the stream of water from the hose and throwing water from the pan with its fore-feet. By $4: 30$ p. m., the animal had become aggressive, attempting to attadk observers through the front of the cage. The bear was silent during this period, whereas normally it had voiced a series of low roars when anyone was near. Excessive salivation began late on the third day, and the animal showed no further interest in food. At $8: 30 \mathrm{a} . \mathrm{m}$. of the fourth day, the bear was restless, moving constantly back and forth and showing interest in any movement made by observers. It again attacked the water in the pan but did not attempt to drink. At approximately $1: 00$ p. m., the animal began rushing from one end of the cage to the other, each time striking violently against the sheet-metal wall at the back. It began to convulse at $1: 40$ p. m., becoming prostrate and comatose in about 10 minutes. Respirations were 104/min. Death occurred at 2:00 p. m. The animal weighed $94 \mathrm{~kg}$., and the extent of eruption of the permanent canine teeth indicated a state of physical development equivalent to that of a wild bear in the second summer of life.

4. A male sibling of the above brown bear received $5,000 \mathrm{MLD}_{50}$ of virus also on 5 March. On the 22nd day following inoculation (27 March), the animal appeared to be normal during the morning; it ate when fed at $3: 00$ p. m., but drank little or no water. Increased salivation was noted between $1: 00$ and $3: 00$ p. m., and saliva was dripping constantly by $4: 30$ p. m. On the second day, salivation had further increased, and the animal remained silent in the presence of observers. By 2:00 p. m., the mouth was being held partially open. The animal was alert to noises or movement outside the cage but was not aggressive. At 4:00 p. m., respirations were 104/min. At $7: 30$ a. $m$. of the third day, the bear was again vocal in the presence of observers, but its behavior was subdued. No food had been consumed; possibly a small amount of water was swallowed in the occasional attempts to drink. Movement of hands in front of the cage caused the animal to back away. By evening, the bear was weak and sat on the haunches most of the time, but reacted somewhat aggressively if provoked. Respirations were $108 / \mathrm{min}$. The animal died during the night. Weight was $82 \mathrm{~kg}$., and the state of physical development was like that of its sibling.

Two other animals became rabid after inoculation (Table 1). A black bear exhibited early incoordination and paralysis, and no aggressive behavior; a brown bear was very active and aggressive during the two days it was clinically rabid. Both animals salivated profusely.

\section{Post-mortem Findings}

Like other carnivores that have died of rabies, most of the bears displayed no macroscopic abnormalities other than some degree of congestion of the 
Rausch in Zentralblatt für Veterinarmedizin Reihe B--Journal of Veterinary Medicine, Series B: Infectious Diseases, Immunology, Food, Hygiene and Veterinary Public Health (1975) 22.

Rabies in Experimentally Infected Bears

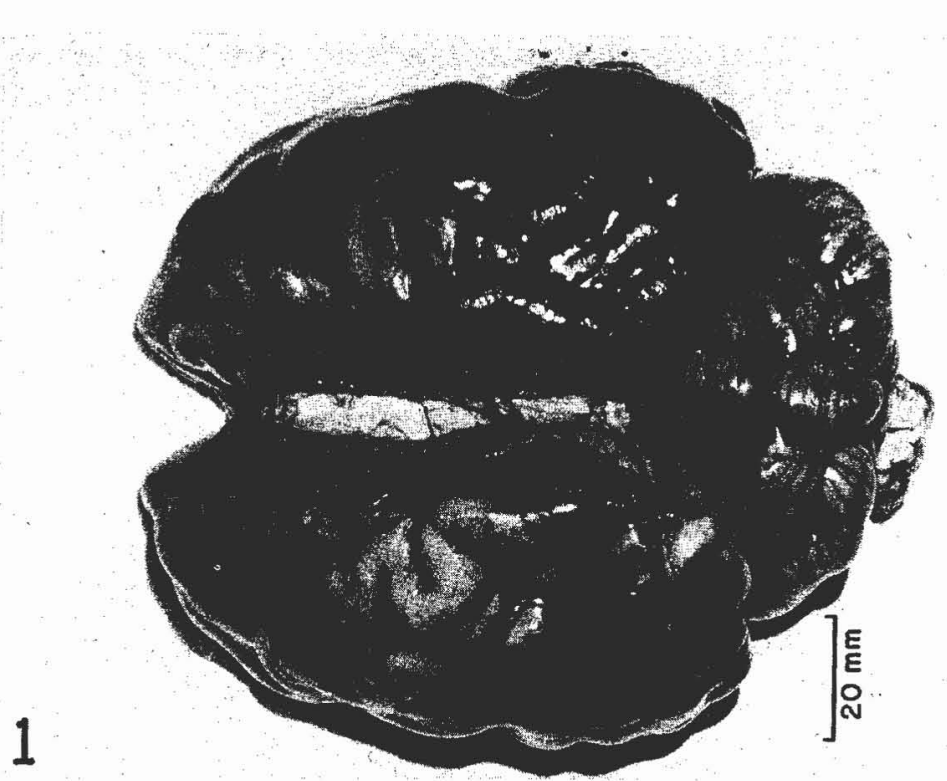

Fig. 1. Brain of brown bear No. 4. Subarachnoid hemorrhage on cerebrum

brain and (or) meninges. Self-mutilation had occurred in only one case, the black bear (No. 1, above) that had abraded the skin of the genital area and adjacent surfaces of the upper legs. In these areas, the subcutaneous tissues were hemorrhagic and edematous to a depth of about $2 \mathrm{~cm}$. In the largest black bear (No. 2), the vessels of the meninges were engorged. The brain of a brown bear (No. 4) exhibited subarachnoid hemorrhage extending over large areas of the cerebrum (Fig. 1), and small clots were present in the lateral ventricles. Transections of the cerebrum after fixation showed the underlying fissures and sulci to be filled with blood. Examination of the surface of the fixed brain under low magnification revealed diffuse hemorrhage from injured subarachnoid vessels. Since the animal was not observed to have been hyperactive during the time it was clinically rabid, these lesions are not attributed to possible trauma. Moreover, considering the extent of the frontal sinuses and the thickness of the parietal muscles in bears, it seems unlikely that traumatic lesions of this kind could be produced by any behavior of a caged animal. The microscopic lesions in the brain of this bear were the most severe observed.

\section{Microscopic Findings}

Among the black bears, microscopic lesions were least evident in the animal (No. 1) in which both the incubation period and the clinical course were longest, and most severe in an animal that died within 2 days after a short incubation period (cf. Table 1). The tissues of the brain were congested in all, and infiltration of leukocytes had occurred around occasional to numerous vessels in the pons, medulla, and cerebral peduncle. In the most severely affected black bear, leukocytes had also infiltrated around vessels in the interfolial sulci and in the molecular layer of the cerebellum. In all, the perivascular infiltrate consisted predominantly of lymphocytes, forming perivascular accumulations up to about $0.060 \mathrm{~mm}$. in thickness. Neither eosinophils nor polymorphonuclear neutrophils were observed in sections. The infiltrating cells were confined to the perivascular spaces, in which hemorrhage was not observed. Gliosis was not marked in the black bears, but the cerebellum of the 
Rausch in Zentralblatt für Veterinarmedizin Reihe B--Journal of Veterinary Medicine, Series B: Infectious Diseases, Immunology, Food, Hygiene and Veterinary Public Health (1975) 22.

most severely affected animal exhibited focal gliosis in the white matter and more diffuse infiltration of the molecular layer adjacent to the granular layer. Extensive degeneration of neurons was characteristic. In all of the rabid black bears, 1 to 3 inclusion bodies, round to oval in outline and usually 0.005 to $0.010 \mathrm{~mm}$. in diameter, were present in the cytoplasm of scattered Purkinje cells in which degenerative changes were not far advanced (cf. Fig. 5).

In sections compared from a normal, laboratory-reared black bear, the cytoplasm of the neurons often contained aggregations of minute, strongly PAS-positive granules. Similar bodies were not observed in sections from rabid animals.

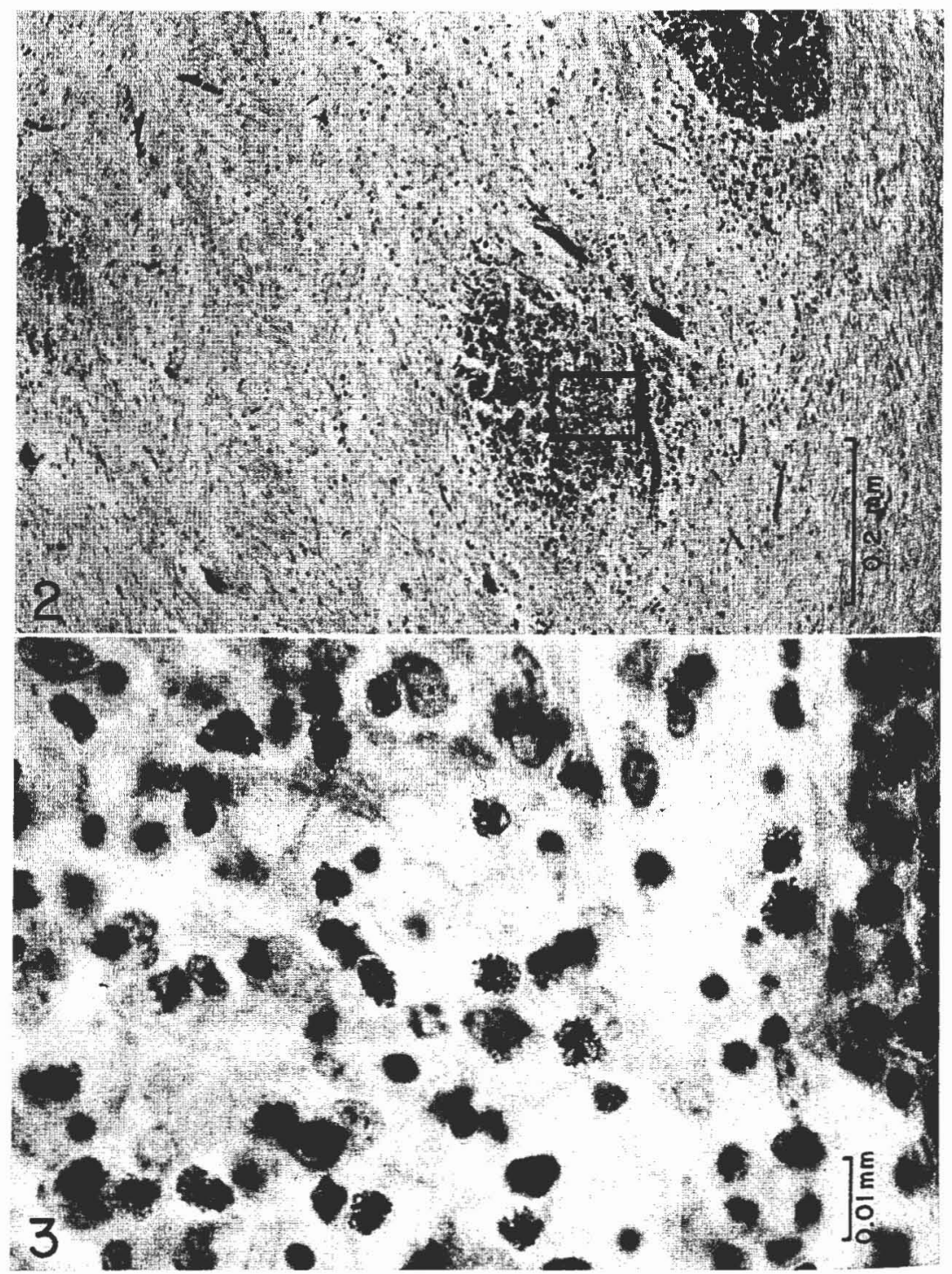

Fig. 2. Section of thalamus of brown bear No. 4, showing diffuse infiltration of eosinophils (dark-staining cells). May-Grünwald Giemsa, green filter

Fig. 3. Higher magnification of area outlined in Fig. 2. Eosinophils. May-Grünwald Giemsa, green filter 
Rausch in Zentralblatt für Veterinarmedizin Reihe B--Journal of Veterinary Medicine, Series B: Infectious Diseases, Immunology, Food, Hygiene and Veterinary Public Health (1975) 22.

In the brown bears, microscopic lesions, present in all tissues examined, exceeded in extent and severity those found in black bears or in naturally or experimentally infected carnivores of other species. The accumulation of blood, with irregularity in layering and differences in degree of hemolysis, seen in sections of the cerebrum of the animal exhibiting subarachnoid hemorrhage (No. 4) suggested that hemorrhaging had occurred for some time preceding death. It contained large numbers of polymorphonuclear neutrophils filled with granules that were negative for hemosiderin by the Prussian blue test, but positive for iron after treatment with hydrogen peroxide. Hemorrhage around superficial cerebral vessels was sometimes confluent with the

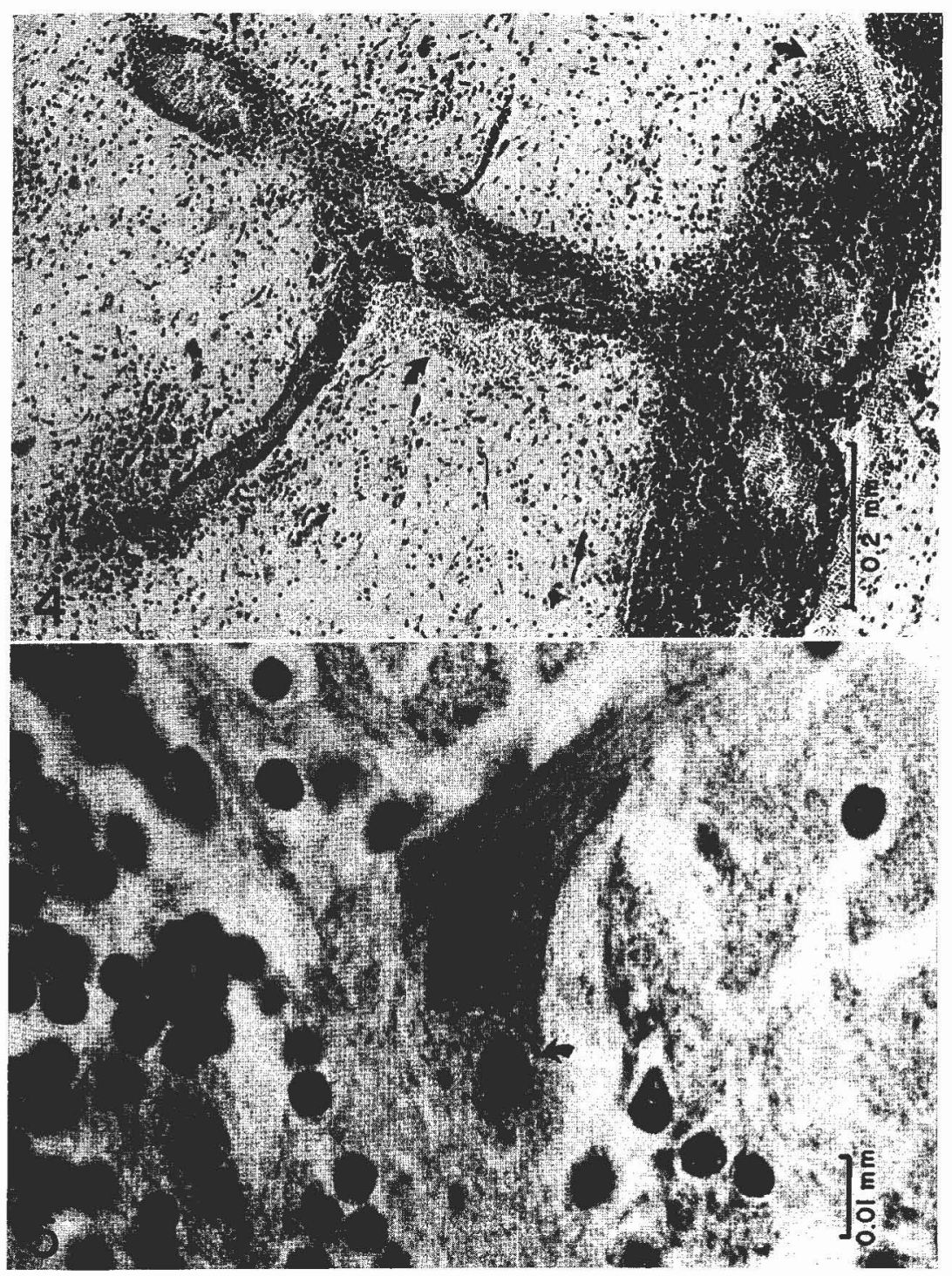

Fig. 4. Section of pons, brown bear No. 4, showing perivascular and diffuse infiltration of cells and perivascular hemorrhage (arrows). May-Grünwald Giemsa, red filter

Fig. 5. Purkinje cell, brown bear No. 3, with intracytoplasmic inclusion (arrow). HematoxylinEosin, green filter 
Rausch in Zentralblatt für Veterinarmedizin Reihe B--Journal of Veterinary Medicine, Series B: Infectious Diseases, Immunology, Food, Hygiene and Veterinary Public Health (1975) 22.

subarachnoid blood. Scattered hemorrhages were present in the cerebral cortex of brown bear No. 3, and occasional focal hemorrhages were noted in other tissues of all 3 brown bears.

In the brown bears also, lesions were prominent in the cerebral peduncle, medulla, pons, and thalamus, those in the pons and thalamus being most severe. Perivascular leukocytes consisted mainly of lymphocytes, but with a large component of eosinophils, especially abundant in animal No. 4 (Figs. 2 and 3). The leukocytes formed perivascular layers up to $0.155 \mathrm{~mm}$. in thickness, of ten extending beyond the perivascular spaces and becoming confluent with cells diffusely infiltrating surrounding tissue (Fig. 4). The latter were predominantly glial cells; whether lymphocytes were present was not determined, but eosinophils were numerous in the infiltrated parenchyma. Infiltration of leukocytes around arteries was noted rarely in the pons and thalamus of animal No. 4. Leukocytic infiltrates were present around occasional vessels in the cerebrum. In all cases, leukocytes had accumulated around the large veins in the interfolial sulci and the vessels in the molecular layer of the cerebellum. Hemorrhage into perivascular spaces was characteristic in the brown bears (Fig. 4). Degenerative changes in neurons had occurred extensively, and inclusion bodies were observed in all 3 brown bears; as in the black bears, they were found only in Purkinje cells (Fig. 5).

In tissues from other rabid animals infected both naturally and experimentally (dogs, coyotes, arctic foxes, and red foxes), microscopic lesions were few. Detailed comparisons were made of tissues from 2 dingoes and 2 coyotes that died in 10 to 20 days after receiving $5,000 \mathrm{MLD}_{50}$ of virus of the inoculum used for black bear No. 2 and the 3 brown bears. In extent and severity, their lesions most closely resembled those in the less severely affected black bears. The tissues of the dingoes were congested, and slight accumulations of leukocytes (lymphocytes and degenerating polymorphonuclear neutrophils) were present around vessels in the cerebral peduncle and thalamus. Neurons exhibited extensive degenerative changes and some had been undergoing phagocytosis. The coyotes had similar but less severe lesions. In one, focal gliosis and slight perivascular infiltration were observed in the white matter ventrally in the cerebellum. In both coyotes, the perivascular infiltrate consisted of lymphocytes and degenerating polymorphonuclear neutrophils. No inclusion bodies were found in the dingoes or the coyotes.

\section{Findings in Wild Bears Involved in Attacks}

During summer, 1963, at least 6 apparently unprovoked attacks by black bears occurred in central Alaska. Brains from 3 of the attacking animals and from 7 others from the same region, some of which reportedly behaved in an unusual manner, were tested for presence of rabies virus with negative results. In one case, a man's body, with severe wounds inflicted by the teeth of a large carnivore, was discovered and left unattended for about an hour, while assistance was sought; when the persons involved returned, a large black bear was found to be feeding on the body, and was shot. It is thus uncertain that the animal tested was responsible for the initial attack. In 1970, a black bear that had injured 4 men in a camp was identified and killed the following day. A large-calibre rifle was used, and the brain was destroyed. Although the subinaxillary salivary glands were negative by the fluorescent antibody test, findings in the experimentally infected bears indicate that the virus of ten may not be present in the salivary glands; consequently, that this animal was rabid is a possibility. Information concerning the wild black bears is summarized in 
Rausch in Zentralblatt für Veterinarmedizin Reihe B--Journal of Veterinary Medicine, Series B: Infectious Diseases, Immunology, Food, Hygiene and Veterinary Public Health (1975) 22.

Rabies in Experimentally Infected Bears

Table 2

Wild black bears (central Alaska) tested for rabies virus

\begin{tabular}{|c|c|c|c|c|}
\hline Sex & Date obt & tained & Locality & Remarks \\
\hline 0 & July & 1963 & Delta Junction & \\
\hline 0 & August & 1963 & Tofty & Associated with fatal attack \\
\hline$\infty$ & August & 1963 & Clear & \\
\hline 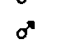 & August & 1963 & Murphy Dome & \\
\hline$\sigma^{x}$ & August & 1963 & Tolovana River, near Minto & $\begin{array}{l}\text { Man injured -- lacerations of } \\
\text { head and neck }\end{array}$ \\
\hline- & August & 1963 & Galena & Man injured -- minor wounds \\
\hline- & August & 1963 & Fort Wainwright & \\
\hline $0^{x}$ & Sept & 1963 & Clear & \\
\hline$\sigma^{x}$ & Sept & 1963 & 61 miles north of Tok & \\
\hline$q$ & Sept & 1963 & Harding Lake & Animal emaciated \\
\hline$\sigma^{x}$ & May & 1970 & Eielson Air Force Base & $\begin{array}{l}\text { Four men injured -- minor } \\
\text { wounds }\end{array}$ \\
\hline
\end{tabular}

Table 2. In cases of attacks by brown bears, the animals either escaped or those killed had been wounded or otherwise provoked.

\section{Epizootiologic Notes and Discussion}

The virus of rabies is perpetuated in the arctic regions of Eurasia and North America among arctic foxes (Siuziumova, 1967; Rausch, 1972). Although the disease also has been recorded frequently in red foxes in Alaska, natural outbreaks of rabies during the past quarter-century (1949-73) have occurred almost exclusively there among foxes in the peripheral treeless regions. Only during 1945-47, was the disease observed among canine populations in the forested interior (WILliams, 1949). The factors that mediate its extension beyond the enzootic regions have not been defined; one essential may be a high numerical density of red foxes in the geographic interior. In Alaska, rabies has been recorded in wild mammals of few species (RAusch, 1972), and never in bears.

Rabies appears to be a rare disease of bears throughout their geographic range. The inclusion of bears in published lists of species of mammals that become infected naturally by the virus is perhaps attributable to an old European report mentioned by Fleming $(1872$, p. 28). The recent literature makes no reference to the occurrence of rabies in bears in Eurasia (cf. EicHWALd and PitzschKe, 1967).

In North America, the first published report of rabies in a bear appears to be that of BALIANTYNe and O'Donoghue (1954), in northern Alberta. Seven additional cases have been confirmed in black bears in Canada: Cté. Rouyn-Noranda, Quebec, September 1958; Trécasson, Quebec, October 1964; St.-Damien de Brandon, Quebec, April 1968; Sault Ste. Marie, Ontario, May 1970; Leeds County, Ontario, November 1970; Carleton County, Ontario, March 1972; and near Maniwaki, Quebec, February 1973 (information provided by Dr. H. TABeL, Canada Department of Agriculture, and Dr. R. O. RAMSDEN, Ontario Department of Lands and Forests). The first record in the United States involved a black bear killed in Gila County, Arizona, in April 1971 (Weekly Morbidity Report, Arizona State Department of Health, week ending 10 April 1971).

Of these 9 animals, 2 attacked and injured persons; 4 exhibited unusual (usually aggressive or violent) behavior; and 3 were found dead. Information was provided by Dr. TABEL concerning the animal found dead near Manning, 
Rausch in Zentralblatt für Veterinarmedizin Reihe B--Journal of Veterinary Medicine, Series B: Infectious Diseases, Immunology, Food, Hygiene and Veterinary Public Health (1975) 22.

Alberta, in January 1953: the body was lying outside the winter den, which contained 2 living cubs; inside the den also was a dead red fox in the mouth and head of which were embedded quills from porcupine, Erethizon dorsatum (Linnaeus). Rabid foxes frequently attack porcupines, as indicated by the presence of quills (see below).

An apparently unprovoked attack at Grand Lake, Colorado, in July 1972 , by a black bear resulted in injury to 2 persons, 1 fatal. The brain of the bear was negative for rabies virus by the fluorescent antibody test and by mouse inoculation (R. E. KEIss, personal communication).

The absence of any indication of the occurrence of rabies in interior Alaska during 1963, and the negative findings in the animals obtained at that time, would seem to exclude rabies as a factor in their attacks on man. The annual pattern of outbreaks in foxes in the enzootic regions does not favor transmission of the virus to bears, since the disease has been most prevalent during winter, when bears are in the dens. There is some evidence that the atypical behavior of black bears in 1963 was attributable to a scarcity of food, possibly in combination with an unusually high numerical density of the animals.

During late summer and autumn of 1963, black bears were attracted in large numbers to sources of food such as garbage-dumps and fish being dried on racks by Indians in fish-camps (e. g., at Rampart, on the Yukon River), and more than usual were killed by hunters and incidentally by local residents in north-central Alaska. At Bettles Field, on the Koyukuk River (lat. $66^{\circ} 55^{\prime} \mathrm{N}$ ), 8 were killed that year during late summer and autumn, compared with a maximum of 2 or 3 in most years. The animals were found to be in poor physical condition ( $R$. REAKOFF, personal communication). Black bears also seemed to be extraordinarily vagile during that period. In northern Alaska they are rarely observed on the tundra north of the latitudinal limits of the boreal forest. During the years 1948-73 (except 1963), the Nunamiut Eskimos in the central Brooks Range killed but 1 black bear north of timber-line (the Nunamiut, personal communications 1949-74); in 1963, they obtained 6 between mid-September and the end of October. Mr. Reakoff observed that black bears were more numerous in 1963 in the forested region along the southern limits of the Brooks Range than at any time since 1957 (when he began flying regularly in the region as a professional guide), and that a marked reduction in their numbers was clearly evident by the spring of 1964 .

HATLER $(1967,1972)$ considered that natural food of black bears was scarce in interior Alaska during autumn, 1963, since blueberry, Vaccinium uliginosum Linneus, did not produce the usual crop of fruit, and he concluded that lack of food accounted for the bears' atypical behavior and aggressiveness. A scarcity of food would be expected to contribute to a high mortality in winter if accumulated fat did not allow survival during the long period (ca. 6 months) of denning. One adult male was killed in mid-winter of 1963-64 while foraging amongst scraps of moose-hide at an isolated residence on Crevice Creek (south-central Brooks Range). The animal was very thin, and its ears and feet were frozen (W. Fickus, personal communication). Among brown bears in interior Alaska during 1963, behavior was not remarkable.

Although the geographic range of the brown bear includes all of mainland Alaska, the animals have been much reduced in numbers or eliminated in populated and relatively accessible areas; few occur in the regions of northern and western Alaska where rabies is enzootic. However, a combination of factors that would seem to favor natural transmission of the virus to brown bears has existed at times in southwestern Alaska. During 1954,1956,1960, and 
Rausch in Zentralblatt für Veterinarmedizin Reihe B--Journal of Veterinary Medicine, Series B: Infectious Diseases, Immunology, Food, Hygiene and Veterinary Public Health (1975) 22.

1969-71, rabies occurred among red foxes on the Alaska Peninsula (Rausch, $1958,1972)$, a region extending about $765 \mathrm{~km}$. southwestward of Lake Iliamna (map, Fig. 6). The apparent sporadic pattern of outbreaks, with no indication of spread from the adjacent mainland, suggests that the disease is

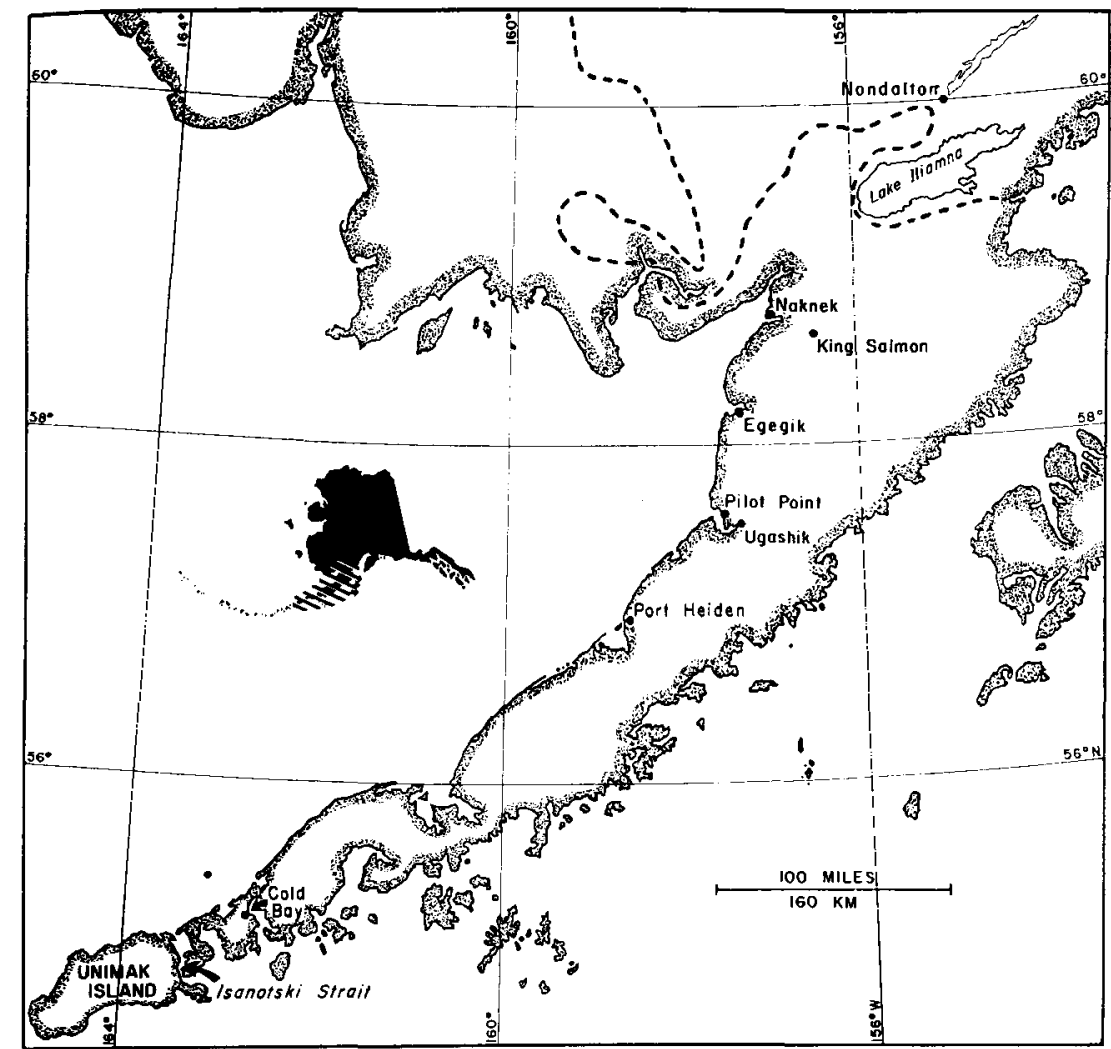

Fig. 6. Map of Alaska Peninsula (cf. inset). Approximate southern extent of boreal forest is indicated by dashed line

enzootic on the peninsula. The region is sparsely populated, which may account for the relative infrequency of records of rabies. Since most of the peninsula is treeless, black bears and other typically forest-inhabiting mammals are absent, but brown bears and other carnivores are numerous. Comparatively detailed information was obtainable concerning the epizootic of rabies in 1969-71, largely through the kind assistance of Dr. R. D. JONEs, Jr., and other biologists of the Aleutian Islands National Wildlife Refuge.

The first indication since 1954 of rabies on the upper Alaska Peninsula was noted in February 1969, when a dog at Egegik became rabid after having been bitten by a fox on 12 January. A dog died of rabies at Naknek in March, but no further cases were confirmed until November and January 1970, when rabid foxes were killed at Pilot Point. During the period March-August 1970, several rabid foxes were obtained on the upper peninsula, and records from new localities during September and October indicated that the disease was progressing southward. A rabid fox was killed at Cold Bay, near the end of the peninsula, in November 1970. Apparently about a year was required for the disease to spread among foxes over a distance of approximately 
Rausch in Zentralblatt für Veterinarmedizin Reihe B--Journal of Veterinary Medicine, Series B: Infectious Diseases, Immunology, Food, Hygiene and Veterinary Public Health (1975) 22.

$460 \mathrm{~km}$. (from Pilot Point). Records from scattered localities during the first half of 1971 indicated that rabies was prevalent among foxes over the entire region, and a case at Nondalton showed that the disease had spread northward beyond Lake Iliamna as well. During 1970-71, red foxes were abundant on Unimak Island, which is separated from the end of the Alaska Peninsula by the $1.6 \mathrm{~km}$. wide Isanotski Strait. Although these waters were ice-covered late in the severe winter of 1970-71, there was no indication that the virus was introduced on the island. In 1971, the last confirmed case was in July, in a fox from Cold Bay.

Only 2 cases were recorded on the peninsula in 1972. On 29 May, a 2 -month-old dog at King Salmon was bitten on the nose by a fox that was confirmed to be rabid. The dog behaved abnormally on the morning of the 8th day following exposure ( 6 June), and was killed; the presence of the virus was later confirmed. The incubation period in this case was the shortest thus far recorded in Alaska in either naturally or experimentally infected animals. In May 1973, and in March 1974, single rabid foxes were obtained from Naknek and Port Heiden, respectively. No cases have been recorded on the peninsula thereafter, nor has there been any indication of spread of the disease inland around the base of the peninsula.

By autumn, 1970, the numerical density of red foxes on the lower Alaska Peninsula had attained the highest level since 1948, when observations by resident biologists began (R. D. JoNES, personal communication). Dr. JONES estimated that there was about 1 fox per $2.5 \mathrm{~km} .{ }^{2}$ for the entire peninsula at elevations below $200-220 \mathrm{~m}$. Mortality was high, as indicated by the many carcasses exposed by melting snow in the spring of 1971, and by the autumn of that year the foxes were at the lowest density observed since 1948.

The rabid foxes were usually aggressive toward dogs and people. Dr. JONEs observed that the rabid animals at Cold Bay wandered about in an aimless manner, but were immediately attracted by movement. However, after an initial lunge in the direction of a moving object, they of ten did not persist in attacking. During the time of the epizootic, rabies was confirmed in

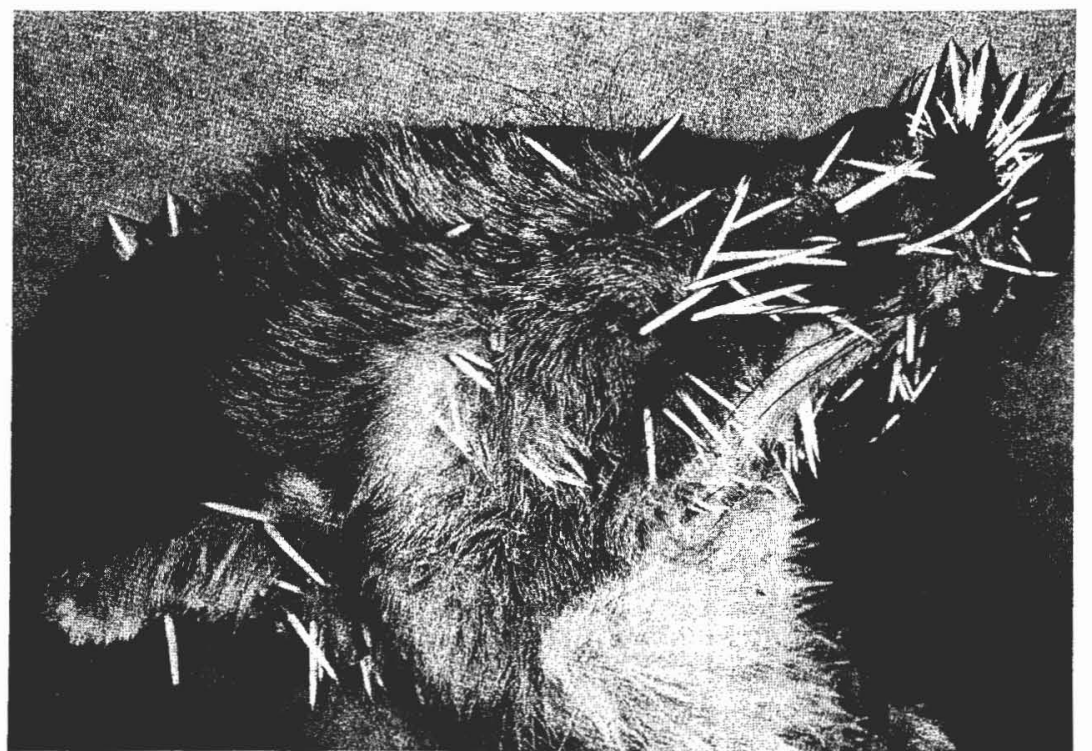

Fig. 7. Rabid red fox with porcupine quills; found dead on 27 November 1970 at Cold Bay 
Rausch in Zentralblatt für Veterinarmedizin Reihe B--Journal of Veterinary Medicine, Series B: Infectious Diseases, Immunology, Food, Hygiene and Veterinary Public Health (1975) 22.

$7 \mathrm{dogs}$, most of which had a history of known contact with foxes, in villages on the peninsula. As in the past in Alaska, there were no known cases of dogto-dog transmission of the virus.

Evidence that rabid foxes attacked other mammals was indirect. Of 34 rabid foxes obtained mainly around settlements, $10(29 \%)$ had quills of porcupines embedded in and around the mouth and sometimes elsewhere on the body (Fig. 7). In contrast, of 21 non-rabid foxes obtained during the same interval, only 1 contained quills. Similar findings in Ontario have been reported by JoHnston and BEAuREgard (1969). There was no indication of rabies among porcupines, whose quills may offer sufficient protection to prevent inoculation, and whose immobility in their usual defense-stance might discourage foxes from persisting in attacks. Among carnivores other than foxes and brown bears, wolves, Canis lupus Linnaeus, were uncommon during the time of the epizootic. Wolverines, Gulo gulo (Linnaeus), and river otters, Lutra canadensis (Schreber), were relatively abundant ( $R$. D. JONES, personal communication). Among species other than foxes, rabies was confirmed in 1 river otter, killed at Port Heiden in May 1971, which was the first and, thus far, only record of the occurrence of rabies in a mammal of the family Mustelidae in Alaska (cf. Rausch, 1972). During the severe winter of 1970-71, numerous sea otters, Enhydra lutris (Linnaeus), were forced onto land when the sea around the lower peninsula became ice-covered (R.D. JonEs, personal communication). Under these conditions, transmission of rabies virus to a marine mammal would have been a possibility.

During the epizootic of 1969-71, contact between rabid foxes and brown bears would seem to have been unavoidable. The seasonal pattern of prevalence of the disease was not so strongly defined as has been observed in the Arctic, and rabid foxes were obviously present and probably numerous during the warm months of 1970-71. In the peninsular region, with its relatively mild climate, brown bears do not remain so long in the dens, and some may be active at any time during winter. Rabies was not recorded in bears during the outbreak, and unusual behavior was reported in only 1 , a subadult that was killed at Naknek in July 1972, when it began pursuing children and dogs. Its brain was negative for the virus by the fluorescent antibody test and by mouse-inoculation.

The physical and ethologic characteristics of bears may have the effect of minimizing the possibility of exposure from the bites of animals as small as foxes. The brown bears on the Alaska Peninsula are perhaps the largest form of $U$. arctos, with adult males attaining weights in excess of $500 \mathrm{~kg}$. To my knowledge, interactions between rabid foxes and brown bears have not been observed, but such animals attempting to attack bears presumably would be quickly killed. The heavy fur of bears also would offer some protection against inoculation of the virus. However, bears typically feed upon carrion and would be expected occasionally to consume foxes dead of rabies. Carcasses of foxes dying in winter, in which the virus would survive until the melting of snow in spring, would seem to constitute attractive food for bears emerging from the dens before an alternative diet of young vegetation is available. Whether bears are susceptible to infection by the oral route has not been investigated; the findings by BELL and MOORE (1971) indicated that other species of carnivores differ in degree of susceptibility to oral infection by rabies virus.

The absence of records of naturally occurring rabies in bears in Alaska and other far-northern regions and the results of work reported here suggest that the quantity of virus inoculated by rabid foxes is usually insufficient to 
infect bears. Sikes (1962) found that the amount of virus excreted in the saliva of foxes (usually less than $100 \mathrm{MLD}_{50}$ in $0.03 \mathrm{ml}$.) is rarely sufficient to infect striped skunks, Mephitis mephitis (Schreber), but that skunks excrete enough to infect other skunks as well as foxes. It is perhaps significant that rabies has been recorded in black bears only within the geographic range of the striped skunk. Two additional species of skunks occur in Arizona, where one case of rabies in a bear was recorded (cf. Hall and Kelson, 1959, pp. 930, 935, and 941). However, the circumstances surrounding the death of the bear found near Manning, Alberta (see above) implicate a fox as the source of infection.

SIKES (1962) observed that the quantity of virus excreted in the saliva of experimentally infected foxes, but not of skunks, usually varied inversely with the quantity of virus that had been inoculated. In both hosts also, the length of the incubation period tended to vary inversely with the quantity of virus inoculated. The experimentally infected bears had little or no virus in the salivary glands (Table 1), and there was no apparent relationship between titre and amount inoculated. The black bear that became rabid after receiving the smallest amount of virus $\left(1,000 \mathrm{MLD}_{50}\right)$ also had the longest incubation period (65 days), but little variation in length of incubation period (16 to 27 days; av. 20 days) was noted in animals that received from 5 to 20 times that amount. The frequent absence of virus in the salivary glands of rabid bears is perhaps characteristic of the species. No information has been obtained concerning possible titres in salivary glands of rabid wild bears.

From 2 black bears that received 1,000 and $5,000 \mathrm{MLD}_{50}$ of virus, serum collected before exposure and at intervals after inoculation, and tested for virus-neutralizing antibodies, was negative to the 64th day following inoculation. One animal was clinically rabid on the 65 th day, after which no further tests were performed. Virus-neutralizing antibody was detected in the serum of only a small proportion of foxes and skunks infected experimentally by Sikes (1962).

Findings in the few animals studied suggest that the inflammatory response differs significantly in the two species of bears. Microscopic lesions were more severe in the brown bears, and the tissue-reaction in this species was distinguished by a large component of eosinophils among the leukocytes in perivascular spaces and among cells diffusely infiltrating the parenchyma. Eosinophils have not been observed in sections from canine animals naturally or experimentally infected by virus of northern origin nor, apparently, in animals infected by strains occurring at lower latitudes.

Observation of inclusion bodies in the Purkinje cells of the bears was a further difference, since Negri bodies have been seldom noted in rabid carnivores in northern regions, whether naturally or experimentally infected, although they have been found sometimes in subinoculated mice (JENKINS and Wamberg, 1960; Kantorovich, 1964; Crandell, 1965). Crandell's findings $(1965,1966)$ suggest that the northern strain of virus differs antigenically from those of regions farther south. Further investigation is required for its adequate characterization.

\section{Acknowledgements}

The bears used in this study were provided by the Alaska Department of Fish and Game. The brown bears were made available by Messrs. K. A. NeILAND, Alaska Department of Fish and Game, and L. G. MilleR, Arctic Health Research Center. Information concerning rabid bears or attacks by bears was furnished by Dr. H. TABEL, Animal Diseases Research Institute, Hull, Quebec; 
Dr. R. O. Ramsden, Wildlife Section, Research Branch, Ontario Department of Lands and Forests, Maple, Ontario; Mr. R. A. Rausch, Alaska Department of Fish and Game, Juneau; and Mr. R. E. Kerss, Wildlife Research Center, Fort Collins, Colorado. Dr. R. D. Jones, Jr., and Mr. E. P. Bailey, Aleutian Islands National Wildlife Refuge, Cold Bay, collected many foxes and provided epizootiologic information. Observations in the Brooks Range were communicated by Messrs. R. Reakoff, Wiseman, and W. Fickus, Crevice Creek; the Nunamiut Eskimos at Anaktuvuk Pass have contributed materials and information since 1949. Drs. V. J. Lewrs and R. E. KIssLing, Center for Disease Control, Atlanta, performed fluorescent antibody tests and provided other technical assistance over several years. At the University of Alaska, Mrs. M. A. SMITH, Geophysical Institute, prepared the electron micrographs, and Dr. R. W. VAN Pelt, Institute of Arctic Biology, provided consultation on some of the tissue sections. At the Arctic Health Research Center, Dr. F. H. FAY and Mrs. V. R. RausCH have contributed to this study since its inception; Dr. J. W. Lindsay reviewed the microscopic findings; Mr. C. Ankrom prepared the sections; and Mr. G. C. KELLEY provided photographic assistance. Messrs. J. Cogan, D. W. Hartbauer, Z. O. Hugo, M. Martin, C. D. RhoDES, and K. R. ZINSMANN were responsible for the care and handling of the animals. I express sincere thanks for these contributions.

\section{Summary}

Ten black bears, Ursus americanus Pallas, and 3 brown bears, $U$. arctos Linnaeus, were inoculated with rabies virus from naturally infected foxes in Alaska. The bears were more resistant than canine species, requiring at least $1,000 \mathrm{MLD}_{50}$ of virus for infection. Low titres or negative results were obtained in salivary glands titrated in mice. Clinical course of the disease, post mortem findings, and microscopic lesions are described. Microscopic lesions were more severe in brown bears, in which the inflammatory response was distinguished by the presence of numerous eosinophils in the perivascular infiltrate and among cells diffusely infiltrating the parenchyma. In both species, inclusion bodies were found only in the Purkinje cells of the cerebellum. Rabies is discounted as a factor in unprovoked attacks by bears on man at high latitudes. The epizootiology of rabies in a region where bears are numerous is discussed, with the conclusion that rabid foxes usually do not excrete sufficient quantities of virus in the saliva to infect bears.

\section{Zusammenfassung}

Tollwut bei experimentell infizierten Bären, Ursus spp., mit epizootiologischen Anmerkungen

Zehn Schwarzbären, Ursus americanus Pallas, und 3 Braunbären, $U$. arctos Linnaeus, wurden mit einem von Füchsen in Alaska isolierten Feldstamm des Tollwutvirus infiziert. Die Untersuchungsergebnisse lassen erkennen, daß Bären eine größere Resistenz gegenüber Tollwutinfektion aufweisen als hundeartige Karnivoren, und zwar konnten sie nicht mit weniger als $1000 \mathrm{MLD}_{50}$ des Tollwutvirus infiziert werden. Das Virus war selten nachweisbar in den Speicheldrüsen der tollwuterkrankten Bären. Klinik und Pathologie der Tollwut bei Bären wurden kurz beschrieben. Die im Gehirn vorkommenden entzündlichen Veränderungen waren bei Braunbären besonders schwer und unterschieden sich durch die Häufigkeit der eosinophilen Leukozyten in den perivasculären und Gewebs-Infiltraten. Bei beiden Arten wurden Einschlußkörper- 
chen nur in den Purkinje-Zellen beobachtet. Die Epizootiologie der Tollwut auf der Alaska-Halbinsel, wo Bären häufig vorkommen, wurde besprochen. Die Ergebnisse deuten an, daß Füchse wenig Virus mit dem Speichel ausscheiden, und selten soviel, daß es für die Infektion von Bären ausreicht.

\section{Résumé}

La rage expérimentale chez les ours, Ursus spp., avec observations épizootiologiques

Dix ours noirs, Ursus americanus Pallas, et 3 ours bruns, $U$. arctos Linnaeus, ont été inoculés avec de virus rabique provenant des renards infectés naturellement dans l'Alaska. Les ours ont été plus résistants au virus que des espèces canines, et pour produire l'infection chez les ours, au moins 1000 $M L D_{50}$ ont été requis. La titration des glandes salivaires chez des souris a données des titres peu élevés ou des résultats négatifs. La course clinique de la maladie, les observations des autopsies, et les lésions microscopiques sont décrites. Les lésions microscopiques les plus sévères ont été observées chez les ours bruns, dans lesquels la réponse inflammatoire a été distinguée par la présence de nombreux éosinophiles dans l'infiltration périvasculaire et parmi les cellules infiltrées diffusément dans le parenchyme. Chez les deux espèces des ours, des corps d'inclusion ont été trouvés seulement dans les cellules de Purkinje du cervelet. On a discuté l'épizootiologie de la rage dans une région où des ours sont nombreux, avec la conclusion qu'il y a dans la salive des renards rabiques une quantité de virus insuffisante pour infecter les ours.

\section{Resumen}

\section{Rabia en osos, Ursus spp., infectados experimentalmente, con anotaciones epizootológicas}

Diez osos negros, Ursus americanus Pallas, y 3 osos pardos, $U$. arctos Lineo, se infectaron con una estirpe campal de virus rábico aislada de zorros en Alasca. Los resultados de la experiencia permiten reconocer que los osos presentan una resistencia mayor frente a la infección rábica que los carnívoros cánidos, pues no se pudieron infectar con menos de $1.000 \mathrm{DML}_{30}$ de virus rábico. El virus era muy raras veces identificable en las glándulas salivales de los osos enfermos de rabia. Se describen sucintamente la clínica y patología de la rabia en los osos. Las modificaciones inflamatorias en el cerebro eran muy graves en el oso pardo y se distinguían por la frecuencia de los leucocitos eosinófilos en los infiltrados perivasculares e hísticos. En ambas especies solo se hallaron corpúsculos de inclusión en las células de Purkinje. Se discute la epizootología de la rabia en la península de Alasca, donde es frecuente la presencia de osos. Los resultados señalan que los zorros eliminan poco virus con la saliva y casi nunca en cantidad tal que fuese suficiente para infectar los osos.

\section{References}

Ballantyne, E. E., and J. G. O'Donoghue, 1954: Rabies control in Alberta. J. Am. Vet. Med. Assoc. 125, 316-326.

BELL, J. F, and G. J. MOORE, 1971: Susceptibility of carnivora to rabies virus administered orally. Am. J. Epidemiol. 93, 176-182.

CRANDELI, R. A., 1965: Laboratory investigation of arctic strains of rabies virus. Acta pth. microbiol. scandinav. 63, 587-596.

CRANDELI, R. A., 1966: Rabies in northern Greenland: some observations on the epizootiology and etiology. In: Proc. Nat. Rabies Sympos., Nat. Comm. Dis. Center, Atlanta, Georgia, 5-6 May, $37-42$. 
Rausch in Zentralblatt für Veterinarmedizin Reihe B--Journal of Veterinary Medicine, Series B: Infectious Diseases, Immunology, Food, Hygiene and Veterinary Public Health (1975) 22.

Rabies in Experimentally Infected Bears

Eichwald, C., und H. Pitzschke, 1967: Die Tollwut bei Mensch und Tier. Gustav Fischer Verlag, Jena.

FLeming, G., 1872: Rabies and hydrophobia: their history, nature, causes, symptoms, and prevention. Chapman and Hall, London.

Hall, E. R., and K. R. Kelson, 1959: The mammals of North America. Ronald Press, New York.

HATIER, D. F., 1967: Some aspects in the ecology of the black bear (Ursus americanus) in interior Alaska. Unpublished M. S. Thesis, Dept. of Wildlife Management, University of Alaska, College, Alaska.

HATLER, D. F., 1972: Food habits of black bears in interior Alaska. Can. Field-Nat. 86, $17-31$.

Jenkins, M., and K. Wamberg, 1969: Rabies discovered in Greenland. J. Am. Vet. Med. Assoc. 137, 183-185.

Johnston, D. H., and M. Beauregard, 1969: Rabies epidemiology in Ontario. Bull. Wildl. Dis. Assoc. S, 357-370.

Kantorovich, R. A., 1964: Natural foci of a rabies-like infection in the far north. J. Hyg., Epidemiol., Microbiol. and Immunol. 8, 100-110.

Mollenhauer, H. H., 1964: Plastic embedding mixtures for use in electron microscopy. Stain Ted. $34,111$.

MuYembe, J. J., A. BrLliau and P. DE SOMER, 1972: Mechanism of resistance to virus challenge in mice infected with Brucella abortus. Arch. ges. Virusforsch. 38, 290-296.

RaUSCH, R. L., 1958: Some observations on rabies in Alaska, with special reference to wild Canidae. J. Wildl. Mgt. 22, 246-260.

Rausch, R. L., 1967: Comparative development of the canine teeth in wild and captive bladk bears, Ursus americanus Pallas. Can. J. Zool. 45, 465-471.

RausCH, R. L., 1972: Observations on some natural-focal diseases in Alaska. Arch. Environ. Health 25, 246-252.

READ, L. J., and H. MUENCH, 1938: A simple method of estimating fifty per cent endpoints. Am. J. Hyg. 27, 493-497.

SIKEs, R. K., 1962: Pathogenesis of rabies in wildlife. I. Comparative effect of varying doses of rabies virus inoculated into foxes and skunks. Am. J. Vet. Res. 23, 1041-1047.

Siuzıumova, L. M., 1967: K izucheniiu epizootologii beshenstva pestsa na Iamale. In: Problemy Severa, No. 11. Promyslovaia fauna krainego severa i ee ispol'zovanie. S. M. UspenskII, Ed. A kad. Nauk SSSR, Moskva, 99-106.

Williams, R. B., 1949: Epizootic of rabies in interior Alaska 1945-47. Can. J. Comp. Med. $13,136-143$.

\section{Addendum}

The continuing presence of rabies on the Alaska Peninsula is indicated by positive findings in 3 red foxes obtained at Egegik on 18 September 1974, 7 January 1975, and 21 March 1975. A further case of unusual behavior in a brown bear has also been noted there. During the night of 2 August 1974, this bear evidently killed and then consumed a 38-year-old man who had been camping near Cold Bay. The following day, a bear found with the aid of a helicopter nearby the camp was shot and its identity confirmed by the presence of human remains in the stomach. The bear was a large male (condylobasal length of the skull: $375 \mathrm{~mm}$.) in its 7 th summer of life, as determined from cemental layers on the canine teeth. Results of the FA test and inoculation of mice were negative for rabies virus. For these animals, the diagnostic tests were performed by Mr. D. G. RITTER, Virology-Rabies Unit, Alaska Division of Public Health, Fairbanks.

Author's address: Dr. R. L. Rausch, Arctic Health Research Center, Fairbanks, Alaska 99701, USA. 